\title{
Antara Ideologi dan gaya hidup Grunge
}

\author{
Irwan Tarmawan, M.Ds \\ Jurusan Desain Komunikasi Visual, Universitas Komputer Indonesia
}

\begin{abstract}
Abstrak. Ideologi sebagai produksi sosial makna sumber pemaknaan dan nilainilai konotatif yang mewujudkan kegunaannya. Nilai-nilai Grunge memberikan suasana yang berbeda sebagai musik rock umumnya, lirik yang dilantunkan, gaya bermain musik, pakaian serta kehidupan keseharian menjadi keyakinan yang mendasari menjadi trend baru. Konotasi dalam produksi sosial makna adalah bertolak belakang dari keadaan umumnya, kekuatan yang muncul dari minoritas. Grunge memiliki pengaruh yang terus meluas, Nirvana salah satu pencetusnya memiliki kekuatan dengan segala keterbatasan grunge itu sendiri untuk terus menunjukan ideologinya ke seluruh penjuru dunia. Menurut Fiske hegemoni diperlukan, dan harus begitu bekerja keras, karena pengalaman sosial kelompokkelompok subordinat (baik berdasarkan kelas, gender, ras, usia, ataupun faktor lain) terus menerus memberikan gambaran yang bertentangan dengan lukisan ideologi dominan yang dibuat untuk mereka oleh mereka sendiri dan relasi sosial. Ideologi yang dominan membentuk hegemoni untuk memenangkan kesepakatan atas apa yang telah diperjuangkan. Secara umum Grunge ingin mencapai tujuannya hanya semata ingin menuangkan ideologinya diatas kemapanan yang sudah ada karena keterkekangannya dalam berkreatifitas. Nirvana berhasil menaklukan ideologinya sendiri untuk memberikan kekuasaan yang besar yang mampu mengalahkan dominasi gender sebelumnya. Grunge adalah Rock and Roll tanpa atribut, begitulah beberapa media massa menyebutnya, namun semakin eksis, menyebar dan meluas Grunge dapat diterima oleh masyarakat walau tidak sedikit yang menuai kebencian sebagian orang. Ketika Grunge menjadi kekuatan komoditas, memberikan penilaianpenilaian atas sikap konsumen untuk memilih style Grunge menjadi gaya hidup dalam kehidupan masyarakat.
\end{abstract}

Kata kunci: Ideologi, Gaya Hidup

\section{PENDAHULUAN}

Sisi lain kehidupan kota Seattle Amerika yang gemerlap, terdapat perkampungan kumuh yang bermunculan kaum-kaum Grunge, mereka makan sehari-harinya dari sampah yang dipungut dan dari koin recehan yang dilempar orang, hidup dari tunjangan sosial pemerintah, tidur dan mabuk di trotoar atau di bangkubangku 
taman, sesekali menodong, melakukan tindak kriminal dan banyak hal lain yang kurang pantas dilakukan hanya sekedar untuk bertahan hidup.

Namun dari kerasnya kehidupan kota Seattle, semakin merebaknya orang-orang Grunge yang membuat resah, memunculkan banyak hal yang menginspirasi bagi kehidupan orang-orang Seattle lainnya. Diantaranya dengan lahirnya musik yang beraliran Seattle Sound. Seattle Sound sempat merajai dunia rock di awal tahun 90an, genre musik inilah yang merubah arah musik rock modern hingga seperti yang sekarang kita dengar. Genre yang dianggap menyingkirkan musik metal dari mainstream musik rock.

Aliran Seattle Sound diusung oleh grup musik lokal di kawasan Seattle dan sekitarnya di Washington. Musisi Seattle pada masa itu memang terisolasi dari perkembangan mainstream musik rock ala Los Angeles dan kota kota besar lainnya di dunia. Di saat dunia dikuasai oleh aliran metal, musisi rock di Seattle mengembangkan jenis musik sendiri, yang lebih dekat ke punk, tetapi lebih sophisticated dari punk. Mulai dari aransemen hingga penggunaan instrumennya. Pada beberapa kasus, lagu-lagu band Seattle lebih melodius. Ada semacam style umum, Soft verse, Hard Chorus. Tetapi juga tidak serumit musik metal. Konsep Seattle Sound cenderung pop, verse-chorus-verse-chorus-solo-choruschorus. Tetapi solo gitar-nya tidak serumit solo ala musik metal. Tema yang di usung sebagai lirik lagu grup-grup musik Seattle adalah tema-tema murung dan kelam. Ya, mirip kondisi cuaca Seattle yang selalu hujan sepanjang tahun. Lirik lagu-lagu band-band Seatle memang cenderung depresif.

Terminologi Grunge sendiri berasal dari kata "Grungy", sebuah idiom yangt bisa diartikan kotor, atau najis. Mark Arm vokalis salah satu pelopor genre musik Grunge yang tergabung dalam Green River kemudian Mudhoney (setelah Green River bubar) yang pertama kali menggunakan istilah tersebut. Kemudian istilah Grunge ini terus dipakai. 
Gaya berpakaian musisi Grunge cenderung tampil apa adanya. Minim aksi panggung, tanpa tata lampu dan gimmick yang berlebih, dan nyaris tidak ada interaksi dengan penonton. Tidak seperti kebanyakan musisi rock pada masa itu yang berpakaianglam, Musisi Seattle menggunakan baju sehari-hari sesukanya, kemeja flanel, jeans usang, t-shirt lusuh, sweater tua, celana selutut yang robekrobek, sepatu kets atau boots yang usang secara umum cenderung kumal, kucel, murahan, benar-benar jauh dari modis, gaya jalanan sejati hingga mirip gembel. Akan tetapi gaya mirip gembel ini menjadi bagian kearah perkembangan komersialisasi industri ke seluruh dunia.

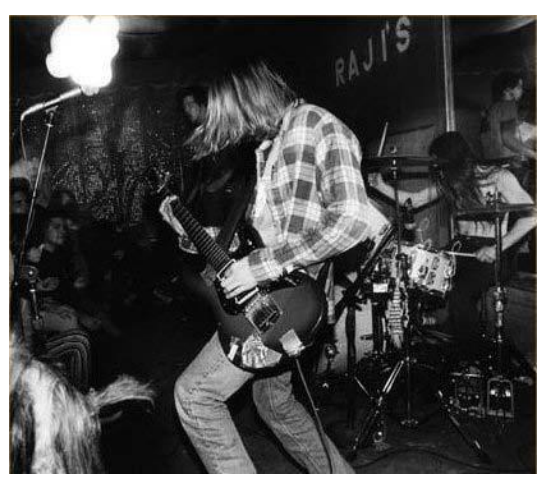

\section{Gambar-1. Aksi Panggung Band Grunge (photobucket.com)}

\section{METODE \& PEMBAHASAN GRUNGE DALAM POPULARITAS DAN KOMODITAS}

Nirvana adalah salah satu grup musik dari Seattle yang membawa aliran grunge masuk ke mainstream musik rock. Satu lagu yang fenomenal dianggap sebagai lahirnya Grunge adalah lagu "Smells Like teen Spirit" di awal tahun 90an. Nirvana berhasil meraih sukses komersial luar biasa. Ini diikuti band-band Seattle lainnya. Ibu kota musik rock pun pindah dari Los Angeles ke Seattle. Seattle Sound atau Grunge adalah fenomena yang mengukir sejarah, bagaimana sebuah aliran baru 'membunuh' aliran mainstream yang begitu mapan, bagaimana aliran ini merubah arah musik rock menjadi seperti yang kita punya sekarang, yang sering disebut dengan 'modern rock' atau 'alternative rock'. 


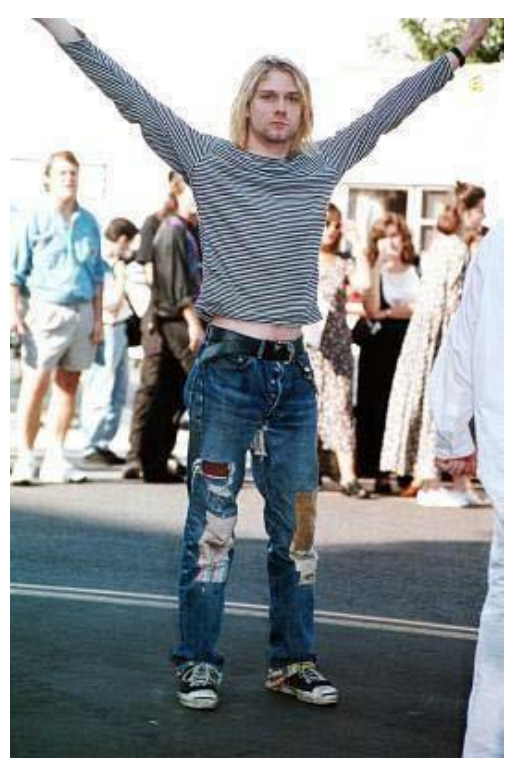

Gambar-2. Vokalis Nirvana "Kurt Cobain" dengan gaya penampilan seadanya yang menjadi trend sebagai gaya grunge (Photobucket.com)

\section{PEMBENTUKAN MODAL GAYA HIDUP GRUNGE}

Menurut Bourdieu (David Chaney:117) bentuk modal ini dengan sendirinya merupakan subjek kompetensi (budaya) diskursif. Dominasi yang dimiliki menjadi pembeda dengan yang lain. Ciri atau identitas mejadi bagian penting dalam pembentukan modal sosial. Kultur yang menjadi modal dasar membentuk kelompok-kelompok yang menyebar memberikan kekuatan menjadi modal sosial.

Ketika popularitas musisi Grunge terus meningkat memberikan simbol-simbol ideologi menjadi kekuatan dan hegemoni yang sebelumnya terbentuk terus semakin menyebar.

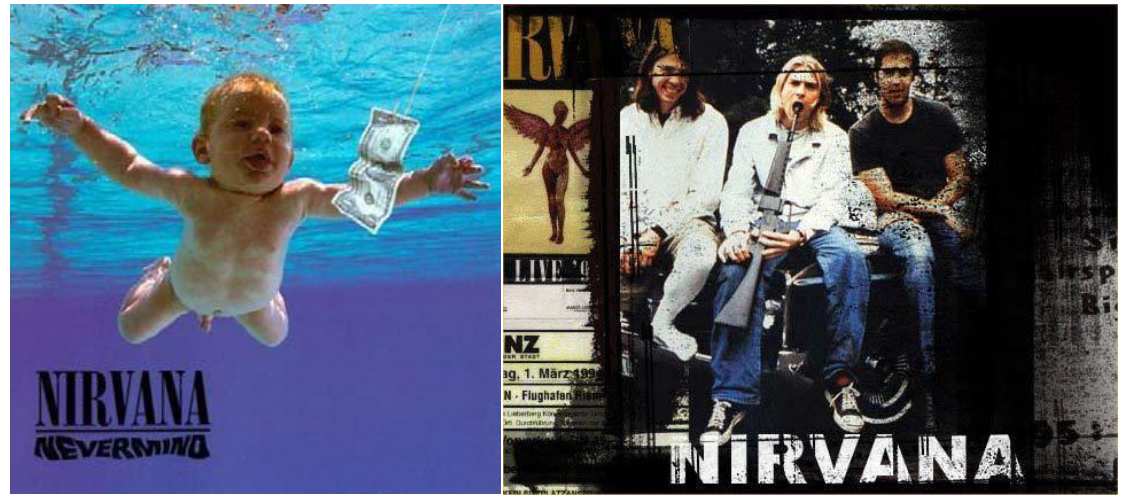


Gambar-3. Nirvana sebagai grup band dengan aliran baru menjadi modal sosial

\section{Grunge (Photobucket.com)}

Seattle memiliki ilusi dan imaginasi yang kuat yang didukung idealisme yang kuat pula sehingga Seattle menjadi kota Grunge. Seperti halnya Nashville untuk country, New Orleans untuk bules, Los Angeles untuk hard rock atau heavy metal, penerobosan gagasan bermusik memberikan kuasa untuk dapat berkuasa dan terus menguasai Grunge, musik yang berbeda dengan jenis musik sebelumnya namun kepercayaan ini cenderung diterima secara tidak kritis sebagai sesuatu yang natural dan tak berubah tanpa ada proses yang rumit dan kritis dari masyarakat dalam menilai musik baru. Terasa dapat memanjakan telinga, di tangkap otak sebagai musik yang penuh semangat, moshing menjadi bagian dari grunge dalam aksi penonton menikmati musik itu. Tidak hanya itu Grunge identik dengan celana bolong, flanel, sepatu kets usang dan kucel menjadi ciri khas musisi grunge.

Ideologi sebagai produksi sosial makna sumber pemaknaan dan nilai-nilai konotatif mewujudkan kegunaannya. Nilai-nilai Grunge memberikan suasana yang berbeda sebagai musik rock umumnya, lirik yang dilantunkan, gaya bermain musik, pakaian serta kehidupan keseharian menjadi keyakinan yang mendasari menjadi trend baru. Konotasi dalam produksi sosial makna adalah bertolak belakang dari keadaan umumnya, kekuatan yang muncul dari minoritas.

Louis Althusser mengatakan ideologi mentransformasikan individu menjadi subyek, dengan menghadirkan mereka posisi. Grunge yang semakin kuat karena keyakinan dari individu-individu untuk melawanan kemapanan sehingga berada dalam posisi yang menjadi semakin kuat, memposisikan grunge menjadi subgenre rock baru yang sampai saat ini terus berkembang. 
Grunge memiliki pengaruh yang terus meluas, Nirvana salah satu pencetusnya memiliki kekuatan dengan segala keterbatasan grunge itu sendiri untuk terus menunjukan ideologinya ke seluruh penjuru dunia. Menurut Fiske (Fiske:243) hegemoni diperlukan, dan harus begitu bekerja keras, karena pengalaman sosial kelompok-kelompok subordinat (baik berdasarkan kelas, gender, ras, usia, ataupun faktor lain) terus menerus memberikan gambaran yang bertentangan dengan lukisan ideologi dominan yang dibuat untuk mereka oleh mereka sendiri dan relasi sosial. Ideologi yang dominan membentuk hegemoni untuk memenangkan kesepakatan atas apa yang telah diperjuangkan. Secara umum Grunge ingin mencapai tujuannya hanya semata ingin menuangkan ideologinya diatas kemapanan yang sudah ada karena keterkekangannya dalam berkreatifitas. Nirvana berhasil menaklukan ideologinya sendiri untuk memberikan kekuasaan yang besar yang mampu mengalahkan dominasi gender sebelumnya.

\section{HABITUS DAN GAYA HIDUP}

Nirvana menjadi ikon Grunge dengan segala atribut yang dibawakannya membawa ke puncak popularitas. Anak muda seluruh penjuru dunia begitu ramai memperbincangkannya. Nirvana menjadi idola membelokan arah menjadi trendsetter baru. Grunge yang dilontarkan media massa sebagai aliran baru yang membawa perubahan, fenomal dan tentunya menjadi komoditi, berdampak pada tingkat konsumsi yang berlebihan. Grunge mewabah, kemeja flanel, jeans usang sobek-sobek, $t$-shirt lusuh, sweater tua, celana selutut yang dirobek, sepatu kets atau boots yang usang secara umum cenderung kumal, kucel, murahan menjadi trend yang semakin digandrungi. Bagi mereka, musik yang mereka mainkan jauh lebih penting dari penampilan itulah yang mendasari penampilan grunge apa adanya. Namun belakangan gaya dandan musisi Seattle ini malah dikemas rumahrumah mode terkenal dan masuk ke industri mode sebagai Grunge style. Hal yang membuat musisi Seattle yang asli menjadi berang. Para remaja diseluruh dunia semakin asik dengan pakaian ala grunge yang dikenakan walau sebagian orang mencibir karena layaknya gembel-gembel yang menghiasi kota di seluruh dunia. 
Menurut Marxis, sifat produksi komoditi dalam sistem kapitalisme tidak semata komoditi dianggap sebagai benda guna (use value), akan tetapi sebagai obyek yang mengandung kekuatan daya pesona tertentu, yang memberikan status tertentu pada orang yang memakainya. Itualah yang terjadi pada pengaruh gaya musisi Grunge menjadikan produk massal yang menyihir berbagai pihak untuk menjadikan pesona Grunge nampak dan terasa liar. Menurut Karl Marx (Graeme Burton:36) Produk-produk budaya adalah komoditas, fetisisme terletak dalam nilai dan kualitas yang dikenakan terhadap produk-produk tersebut. Objek magis memberikan status sosial terhadap pemakainya.

Munculnya trend baru dalam berpakain ala grunge dan grup-grup musik baru di seluruh penjuru dunia yang juga mengusung aliran Grunge, tetapi mereka lebih ke style dan fashion-nya saja. Spirit Seattle Sound-nya tidak ada. Ini nampak pelbagai komoditas yang difetisasi membebani konsumen untuk kepentingan produsen.Begitu hebatnya Nirvana menjadi ikon Grunge, membawa dampak terhadap berbagai aspek dengan ideologi yang menjadi habitus anak muda di dunia.

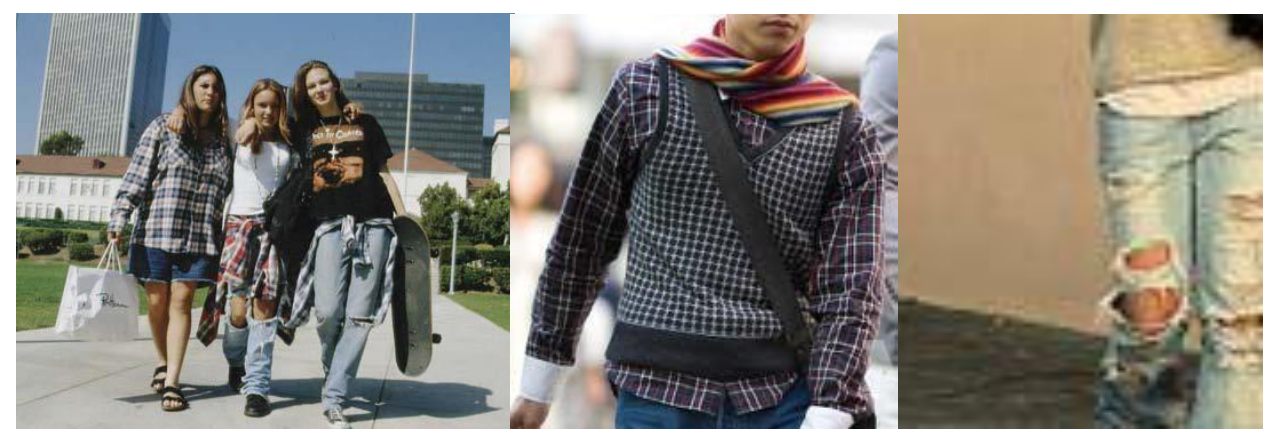

Gambar-4. Pakaian ala Grunge yang mewabah, sebagai habitus dalam cara berpakaian (Photobucket.com) 


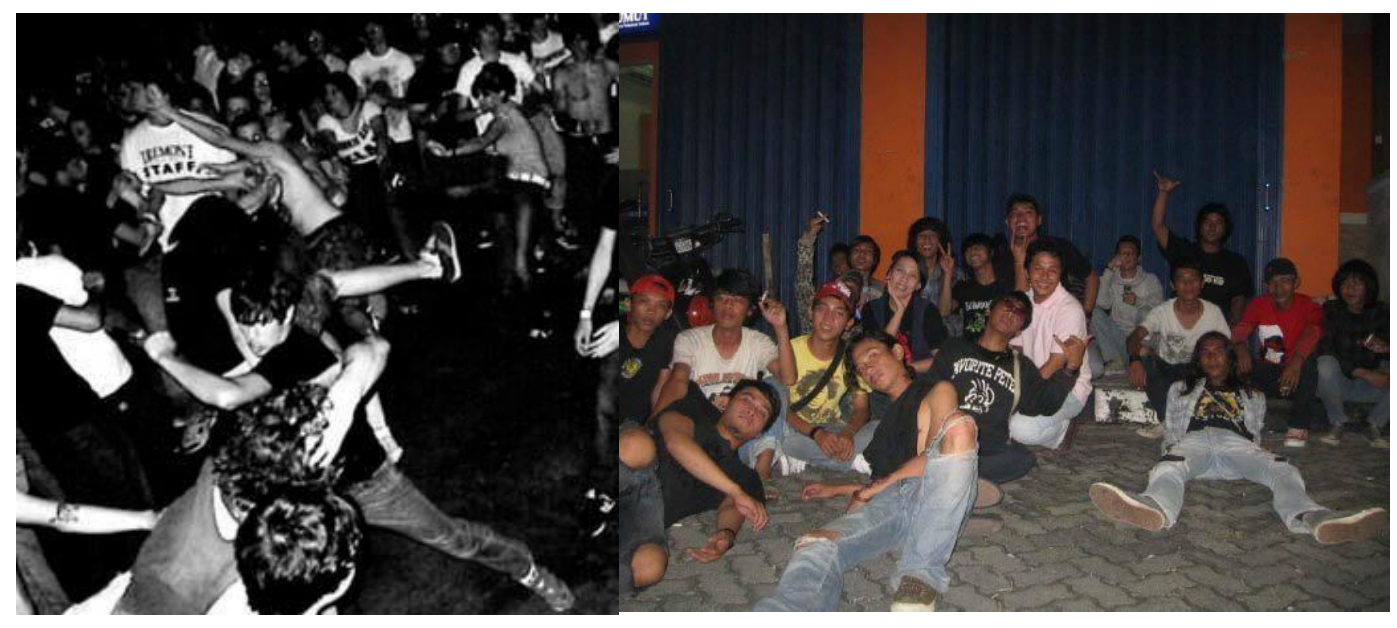

Gambar-6. Moshing salah satu aksi yang dilakukan saat menuangkan kepuasan menikmati musik Grunge, serta anak muda Indonesia yang menjadi bagian dari kehidupan Grunge. (Photobucket.com dan pikiran-rakyat.com)

\section{KESIMPULAN}

Grunge adalah Rock and Roll tanpa atribut, begitulah beberapa media massa menyebutnya, namun semakin eksis, menyebar dan meluas Grunge dapat diterima oleh masyarakat walau tidak sedikit yang menuai kebencian sebagian orang. Ketika Grunge menjadi kekuatan komoditas, memberikan penilaianpenilaian atas sikap konsumen untuk memilih style Grunge menjadi gaya hidup dalam kehidupan masyarakat. Grunge bukanlah gaya hidup yang mereka anut walaupun mereka memainkan musik Grunge, tetapi lebih pada unsur bahwa Grunge is Soul yang mencerminkan tentang kejiwaan yang redup, bercerita tentang sisi lain dari dunia yang orang lain menganggapnya sinting dan lebih pada sifat koreksi pada diri sendiri, namun gaya berpakaian dan kebebasannya tetap menjadi trend. Sampai pada titik puncaknya Grunge mengalami penurunan dan ketika Nirvana bubar berhentilah grunge, berhentilah hegemoni yang telah dibangun.

\section{DAFTAR PUSTAKA}

Burton, Graeme. 2008. Media dan Budaya Populer. Yogyakarta. Jalasutra. 
Chaney, David. 2009. Lifestyle: Sebuah Pengantar Komprehensif. Yogyakarta dan Bandung. Jalasutra.

Choky, Gilbert. 2009. Kurt Cobain. Jakarta. Shira Media.

Fiske, John. 2006. Cultural and Communication Studies. Yogyakarta dan Bandung. Jalasutra.

Bisnisindonesia.com

Grungeindonesia.com

Photobucket.com

Pikiran-rakyat.com 